\title{
GB Virus C/Hepatitis G Virus Infection in Dialysis Patients and Kidney Transplant Recipients in Central Brazil
}

\author{
Ramon Ramos Filho, Megmar AS Carneiro, Sheila A Teles, Márcia A Dias, \\ Divina D P Cardoso, Elisabeth Lampe*, Clara FT Yoshida*, Regina M B Martins/ ${ }^{+}$
}

Instituto de Patologia Tropical e Saúde Pública, Universidade Federal de Goiás, Caixa Postal 131, 74605-050 Goiânia, GO, Brasil

*Departamento de Virologia, Instituto Oswaldo Cruz-Fiocruz, Rio de Janeiro, RJ, Brasil

In order to investigate the prevalence of $G B$ virus $C(G B V-C) /$ hepatitis $G$ virus $(H G V)$ infection in dialysis patients and kidney transplant recipients in Central Brazil and also to analyze the virus genotypes distribution, $a$ total of 123 patients including 98 on hemodialysis, 13 on continuous ambulatory peritoneal dialysis treatment, and 12 who received kidney transplantation were interviewed in one unit of dialysis treatment in Goiannia city. Blood samples were collected and serum samples tested for GBV-C/HGV RNA by polymerase chain reaction. Genotypes were determined by restriction fragment length polymorphism (RFLP) analysis. Eighteen samples were GBV-C/HGV RNA-positive, resulting in an overall prevalence of $14.6 \%$ (95\% CI: 9.2-21.7). A high positivity for GBV-C/HGV RNA was observed in patients who had received kidney transplant (16.7\%), followed by those on hemodialysis (15.3\%), and peritoneal dialysis (7.7\%). RFLP analysis revealed the presence of genotypes 1, 2, and 3 of GBV-C/HGV; more precisely, 9 (50\%) samples were found belonging to the $2 b$ subtype, $4(22 \%)$ to the $2 a$ subtype, $3(17 \%)$ to genotype 1 , and $2(11 \%)$ to genotype 3. The present data indicate an intermediate prevalence of GBV-C/HGV infection among dialysis patients and kidney transplant recipients in Central Brazil. Genotype 2 (subtype $2 b$ ) seems to be the most prevalent $G B V-C / H G V$ genotype in our region.

Key words: hepatitis G virus - GB virus C - dialysis - kidney transplant - Central Brazil

GB virus $\mathrm{C}(\mathrm{GBV}-\mathrm{C})$ and hepatitis $\mathrm{G}$ virus (HGV) are different isolates of the same virus which were identified by two independent research groups (Simons et al. 1995, Linnen et al. 1996). Although it was initially identified as possible aetiological agent of viral hepatitis in humans, and despite its similarity in genome structure with hepatitis $\mathrm{C}$ virus (HCV), it is unlikely that $\mathrm{GBV}-\mathrm{C} / \mathrm{HGV}$ is a cause of liver diseases (Zhu et al. 2003). Nevertheless, several recent studies have addressed that patients infected with human immunodeficiency virus (HIV) showed a beneficial effect of co-infection with GBV-C/HGV. The benefit is demonstrated by lower progression to acquired immunodeficience syndrome (AIDS) and prolonged survival time after its development (Yeo et al. 2000, Tillmann et al. 2001, Xiang et al. 2001, Muerhoff et al. 2003).

GBV-C/HGV is an envelope positive-stranded RNA virus with a genome of about $9.4 \mathrm{~kb}$ belonging to the Flaviviridae family. At least five major genotypes of this virus have been proposed by sequence analysis of the 5 ' non-coding region ( ${ }^{\prime}$ NCR) or E2 gene. Genotype 1 is found mainly in West Africa, while genotype 2 is the most common in the US and Europe. Genotype 3 is frequently observed in parts of Asia (Muerhoff et al. 1996, 1997, Mukaide et al. 1997, Okamoto et al. 1997, Katayama et al.

Financial support: Conciteg, $\mathrm{CNPq}$

${ }^{+}$Corresponding author. Fax: +55-62-521.1839. E-mail: rbringel@ terra.com.br

Received 5 April 2004

Accepted 9 September 2004
1998). Recent studies have identified genotype 4 in samples from Myanmar, Vietnam, and Indonesia (Naito et al. 2000, Handajani et al. 2000), and genotype 5 in South Africa (Tucker et al. 1999, Tucker \& Smuts 2000).

$\mathrm{GBV}-\mathrm{C} / \mathrm{HGV}$ is transmitted mainly by parenteral route. Thus, patients with chronic renal failure are at high risk of acquiring this virus because they need frequent blood transfusions and undergo medical procedures that accompany bleeding. There are conflicting data about GBV-C/ HGV RNA prevalence in chronic hemodialysis patients; studies showed rates ranging from 3.1\%, in Japan (Masuko et al. 1996), to 57.5\%, in France (de Lamballerie et al. 1996). On the other hand, few reports are available in patients on peritoneal dialysis treatment or in kidney transplant recipients. In Brazil, data concerning GBV-C/HGV infection in hemodialysis patients are still rare (Lampe et al. 1997, Watanabe et al. 2003), and little is known about the genetic diversity of GBV-C/HGV strains circulating in our country (Gallian et al. 1998, Lampe et al. 1998, Oliveira et al. 2002). In the present study we aimed at knowing the prevalence of GBV-C/HGV RNA in hemodialysis patients in Central Brazil and also to analyze the virus genotypes distribution. Moreover, we studied the GBV-C/HGV epidemiology in an additional group of patients on peritoneal dialysis treatment and kidney transplant recipients.

\section{MATERIALS AND METHODS}

Subjects - This study was carried out in one unit of dialysis treatment in Goiânia city (1,000,000 inhabitants), Central Brazil. Between January and March 2000, all 123 patients including 98 on hemodialysis, 13 on continuous ambulatory peritoneal dialysis treatment, and 12 who received kidney transplantation were asked to take part of 
this study, and informed consent was obtained from all of them. The study was approved by the Ethical Committee of the Federal University of Goiás.

A standardized form was used to collect sociodemographic data as number of previous blood transfusions, length of time on dialysis, kidney transplantation, acupuncture, tattooing, intravenous drug use, dental procedure with non-licensed dentist, multiple sex partners, sexually transmitted diseases, and possible household contact with hepatitis.

The studied population ranged in age from 16 to 86 years (average 52.5 years). Sixty ( $48.8 \%$ ) were females and $63(51.2 \%)$ were males. The aetiology of chronic renal failure was diabetic nephropathy $(n=30)$, hypertension and nephrosclerosis $(\mathrm{n}=25)$, chronic glomerulonephritis $(\mathrm{n}=$ 17), polycystic kidney disease $(\mathrm{n}=11)$, pyelonephritis $(n=5)$, renal diseases of unknown aetiology $(n=27)$, and others $(\mathrm{n}=8)$.

Serological tests - Blood samples were collected from all patients and sera were stored at $-20^{\circ} \mathrm{C}$. They were screened for hepatitis B surface antigen (HBsAg), hepatitis B core antibody (anti-HBc), hepatitis B surface antibody (anti-HBs), and hepatitis C antibody (anti-HCV) by enzyme-linked immunosorbent assays (ELISA) (Abbott Laboratories, US). All samples were also tested for alanine aminotransferase (ALT) levels by a colorimetric method (Dolles Laboratory, Brazil).

Detection of $G B V-C / H G V$ and $H C V R N A$ - All samples were submitted to RNA extraction, reverse transcription, and a nested PCR with primers complementary to the conserved area of the NS5 region of the GBV-C/HGV genome, essentially as described by Lampe et al. (1997). For HCV RNA detection, primers complementary to the conserved area of the 5' NCR of HCV were used (Ginabreda et al. 1997).

GBV-C/HGV genotyping - GBV-C/HGV RNA-positive samples were amplified by PCR using primers complementary to the 5' NCR. Genotypes were determined by means of RFLP method (Quarleri et al. 1999). Briefly, amplicons were initially cleaved with Hinf I, and depending on the restriction pattern observed, a second digestion was performed either with Aci I or Aat II. Restriction fragments were resolved in ethidium bromide-stained 3\% agarose gels.

Statistical analysis - Prevalence and $95 \%$ confidence intervals (CI) were calculated. Chi-square test or Fisher's exact test were performed to evaluate the distribution of characteristics associated with GBV-C/HGV infection. Statistical significance was assessed at the 0.05 probability level in all analyses. Statistical evaluations were performed using Epiinfo 6.0 program developed by the Centers for Disease Control and Prevention (Atlanta, GA).

\section{RESULTS}

As shown in Table I, an overall prevalence of $14.6 \%$ (95\% CI: 9.2-21.7) was found for GBV-C/HGV infection in patients with chronic renal failure. A higher positivity for GBV-C/HGV RNA was observed in patients who had received kidney transplant $(16.7 \%)$, followed by those on hemodialysis (15.3\%) and peritoneal dialysis $(7.7 \%)$.

There was no association between GBV-C/HGV RNA and age, sex, history of blood transfusion, length of time on dialysis ( $p>0.05)$. Analysis of the characteristics of GBV-C/HGV RNA-positive patients is shown in Table II. These individuals ranged in age from 23 to 71 years. Eleven $(61.1 \%)$ were men. The majority of them was on hemodialysis and had less than one year of treatment. Two subjects received kidney transplant. Only one patient was on peritoneal dialysis. Almost $90 \%$ of these infected patients had history of blood transfusion. Four (22.2\%) of the GBVC/HGV RNA-positive patients were co-infected with HCV (anti-HCV and HCV RNA positive). Two of them, were also positive for anti-HBc and anti-HBs markers. All but one GBV-C/HGV infected individuals had normal ALT levels.

All 18 GBV-C/HGV RNA-positive samples were genotyped by RFLP pattern. It was observed that $3(17 \%)$ were of genotype $1,13(72 \%)$ of genotype 2 , and $2(11 \%)$ of genotype 3. In samples identified as genotype 2, 4 (22\%) belonged to subtype $2 \mathrm{a}$ and 9 (50\%) to subtype $2 \mathrm{~b}$ (Figure).

\section{DISCUSSION}

The present study represents the first investigation of GBV-C/HGV infection in patients with chronic renal failure in Goiânia city, Central Brazil. A high overall prevalence $(14.6 \%)$ was found, when compared to that observed in blood donors (7.1\%) from the same region (Oliveira et al. 2002).

A positivity rate of $7.7 \%$ was detected on patients on peritoneal dialysis, which was similar to that reported in local blood donors (Oliveira et al. 2002). These patients are on continuous ambulatory peritoneal dialysis, a home therapy that reduces the risk for nosocomial transmission. As the number of patients studied was small, further investigations are necessary to provide more information on the epidemiology of GBV-C/HGV infection among patients on peritoneal dialysis treatment.

TABLE I

Prevalence of GB virus C/hepatitis G virus RNA in dialysis patients and kidney transplant recipients in Central Brazil

\begin{tabular}{lrcr}
\hline Renal replacement therapy & $\mathrm{n}$ & Prevalence $(\%)$ & $95 \%$ CI \\
\hline Peritoneal dialysis & 13 & 7.7 & $0.4-32.5$ \\
Hemodialysis & 98 & 15.3 & $9.2-23.5$ \\
Kidney transplantation & 12 & 16.7 & $2.9-45.1$ \\
\hline Total & 123 & 14.6 & $9.2-21.7$ \\
\hline
\end{tabular}

CI: confidence interval 
TABLE II

Characteristics of $18 \mathrm{~GB}$ virus C/hepatitis G virus RNA-positive patients with chronic renal failure

\begin{tabular}{|c|c|c|c|c|c|c|c|c|}
\hline \multirow[b]{2}{*}{ Patient } & \multirow{2}{*}{$\begin{array}{l}\text { Age } \\
(\mathrm{yr})\end{array}$} & \multirow[b]{2}{*}{ Gender } & \multirow{2}{*}{$\begin{array}{c}\mathrm{Nr} \text { of } \\
\text { transfusions }\end{array}$} & \multicolumn{2}{|c|}{ Renal therapy } & \multirow[b]{2}{*}{$\mathrm{HBV}$} & \multirow[b]{2}{*}{$\mathrm{HCV}$} & \multirow[b]{2}{*}{ ALT } \\
\hline & & & & Type & Duration & & & \\
\hline 1 & 38 & M & 1 & $\mathrm{HD}$ & < 1year & - & - & 25 \\
\hline 2 & 36 & M & $>10$ & $\mathrm{TX}$ & $>3$ years & + & + & 73 \\
\hline 3 & 23 & M & 8 & PD & < 1year & - & - & 6 \\
\hline 4 & 48 & M & 2 & HD & 1- 3 year & - & - & 22 \\
\hline 5 & 59 & $\mathrm{M}$ & 9 & HD & $<$ 1year & - & - & 28 \\
\hline 6 & 67 & M & 8 & $\mathrm{HD}$ & $<$ 1year & - & - & 16 \\
\hline 7 & 41 & M & 4 & HD & $<$ 1year & - & - & 18 \\
\hline 8 & 59 & M & 8 & $\mathrm{HD}$ & 1- 3 year & - & - & 40 \\
\hline 9 & 52 & $\mathrm{~F}$ & 3 & HD & 1- 3 year & - & + & 14 \\
\hline 10 & 33 & M & 1 & $\mathrm{TX}$ & $>3$ years & + & + & 19 \\
\hline 11 & 63 & M & 0 & HD & $<$ 1year & - & - & 5 \\
\hline 12 & 66 & $\mathrm{~F}$ & 0 & HD & $<$ 1year & - & - & 32 \\
\hline 13 & 47 & M & 3 & $\mathrm{HD}$ & $<$ 1year & - & - & 23 \\
\hline 14 & 28 & $\mathrm{~F}$ & 3 & HD & $<$ 1year & - & - & 10 \\
\hline 15 & 51 & $\mathrm{~F}$ & 3 & HD & $<$ 1year & - & - & 27 \\
\hline 16 & 69 & $\mathrm{~F}$ & 1 & $\mathrm{HD}$ & $<$ 1year & - & - & 14 \\
\hline 17 & 70 & $\mathrm{~F}$ & 3 & HD & $<$ 1year & - & + & 21 \\
\hline 18 & 71 & $\mathrm{~F}$ & 3 & HD & $<$ 1year & - & - & 14 \\
\hline
\end{tabular}

TX: kidney transplantation; PD: peritoneal dialysis; HD: hemodialysis; HBV: hepatitis B virus; HCV: hepatitis C virus; ALT: alanine aminotransferase

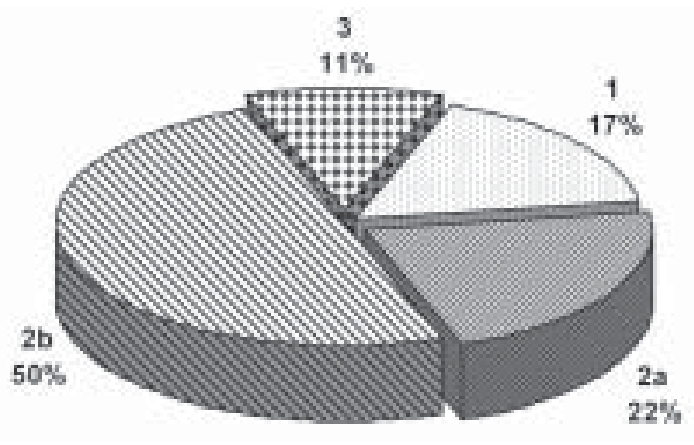

Frequency of GB virus C/hepatitis G virus genotypes in patients with chronic renal failure in Central Brazil.

Regarding hemodialysis patients, GBV-C/HGV RNA prevalence rates range from 3.1\% to 15\% in Japan (Masuko et al. 1996, Shibuya et al. 1998), from $11.5 \%$ to $20 \%$ in the US (Bastani et al. 1998, Medina et al. 1998) and from 6\% to 57.5\% in Europe (de Lamballerie et al. 1996, Fabrizi et al. 1997). It has also been reported a high rate (55\%) in Indonesia (Tsuda et al. 1996). In South America, a prevalence of $17.6 \%$ was observed in Argentina (Fernandez et al. 2000). In addition, rates of $15 \%$ and $12.8 \%$ were detected in Rio de Janeiro and Ribeirão Preto, Brazil (Lampe et al. 1997, Watanabe et al. 2003), which were similar to the prevalence of $15.3 \%$ found in Goiânia. Thus, GBV-C/HGV prevalence infection in Brazilian hemodialysis patients could be placed in an intermediate position.

In the present study, the frequency of detectable GBVC/HGV RNA in serum was higher in kidney transplant recipients $(16.7 \%)$ than among hemodialysis patients. Similar results were observed in Germany (15.2\% x 9.7\%)
(Szabo et al. 1997) and Italy (6\% x 3.6\%) (Fabrizi et al. 1997). It is possible that the immunosuppressive regimen used may enhance GBV-C/HGV replication, either directly or indirectly through its activity on the host's immune system. In addition, this infection may occur during dialysis treatment, at the time of or after kidney transplantation, or due to blood transfusions (Fabrizi \& Martin 1999). However, as the number of kidney transplant recipients studied was small, more studies are needed to confirm this observation.

These differences in the prevalence of GBV-C/HGV infection may also be explained by epidemiological variations, including the size and the clinical features of the patients, methods of detection of GBV-C/HGV RNA (especially the use of different primers), duration of dialysis treatment, infection control measures practiced in the dialysis unit, and geographic factors (Hassan \& Bastani 2000).

Almost 90\% of the GBV-C/HGV RNA-positive patients had history of blood transfusion. This finding rate was in agreement with the studies of Masuko et al. (1996) and Fabrizi et al. (1997) who found a history of transfusion in $75 \%$ and $80 \%$ of hemodialysis patients infected with GBV$\mathrm{C} / \mathrm{HGV}$, respectively. On the other hand, the GBV-C/HGV RNA was detected in two hemodialysis patients with no transfusion history and without any other risk of parenteral exposure, supporting the hypotesis of nosocomial transmission.

Prevalence rates of $26 \%$ and $37.4 \%$ were found for hepatitis B and C, respectively (data not shown). Of the 18 GBV-C/HGV RNA-positive patients, 4 (22.2\%) were coinfected by HCV. Among them, two were positive for anti$\mathrm{HBc}$ and anti-HBs. In addition, no association was found between GBV-C/HGV RNA positivity and serum ALT lev- 
els. These data indicate that this virus has been independently widespread in patients with chronic renal failure in Central Brazil.

All GBV-C/HGV RNA-positive samples were genotyped by RFLP. Genotype $2(72 \%)$ was the most prevalent, followed by genotype $1(17 \%)$, and $3(11 \%)$. Genotypes 1 and 2 were detected by Gallian et al. (1998) in a rural population in the state of Ceará and also by Lampe et al. (1998) in individuals living in Rio de Janeiro. The presence of both genotypes in Brazil is likely to reflect the European and African origin of the population. In this study, genetic diversity of genotype 2 revealed the predominance of subtype $2 \mathrm{~b}$ in patients with chronic renal failure. Recently, this subtype was also dominant (53.8\%) in blood donors in Goiânia, it was followed by subtype 2a (28.6\%) and genotype 1 (17.6\%) (Oliveira et al. 2002). On the other hand, $2(11 \%)$ patients with chronic renal failure were infected with genotype 3 . This is the first related of the occurrence of genotype 3 in Brazil. Although this genotype was not detected previously in our country (Gallian et al. 1998, Lampe et al. 1998, Oliveira et al. 2002), it was observed in Colombia (Tanaka et al. 1998), Argentina (Quarleri et al. 1999), and Bolivia (Konomi et al. 1999). Probably, its presence in South America reflects the immigration from Asia, where genotype 3 is prevalent (Tucker \& Smuts 2000).

In conclusion, our data point out an intermediate endemicity of GBV-C/HGV infection in dialysis patients and kidney transplant recipients in Central Brazil. The presence of strains belonging to genotypes $1,2 \mathrm{a}, 2 \mathrm{~b}$, and 3 reveals a large genetic diversity of GBV-C/HGV circulating in Brazil.

\section{ACKNOWLEDGEMENTS}

To KP Souza and LA Oliveira for technical support.

\section{REFERENCES}

Bastani B, Frenche D, Gellens M, Di Bisceglie A 1998. Infection with hepatitis $\mathrm{G}(\mathrm{HGV})$ and hepatitis $\mathrm{C}(\mathrm{HCV})$ viruses in patients on chronic hemodialysis. Am J Nephrol 9: 199A.

De Lamballerie X, Charrel RN 1996. Hepatitis GB virus C in patients on hemodialysis. N Engl J Med 334: 1549.

Fabrizi F, Martin P 1999. GBV-C/HGV infection in end-stage renal disease. J Nephrol 12: 131-139.

Fabrizi F, Lunghi G, Bacchini G, Corti M, Guarnori I, Raffaele L, Erba G, Pagano A, Locatelli F 1997. Hepatitis G virus infection in chronic dialysis patients and kidney transplant recipients. Nephrol Dial Transplant 12: 1645-1651.

Fernandez JL, Valtuille R, Hidalgo A, Del Pino N, Lef L, Rendo P 2000. Hepatitis G virus infection in hemodialysis patients and its relationship with hepatitis $\mathrm{C}$ virus infection. Am J Nephrol 20: 380-384.

Gallian P, Rodrigues V, Cantaloube JF, Dessein H, Micco P, Dessein AJ, Lamballeri X 1998. High prevalence of GB-C/ hepatitis $\mathrm{G}$ virus in a Brazilian population with helminth infection. J Med Virol 56: 310-315.

Ginabreda MGP, Yoshida CFT, Niel C 1997. Genomic characterization of Brazilian hepatitis $\mathrm{C}$ virus genotypes 1a and 1b. Braz J Med Biol Res 30: 339-345.

Handajani R, Soetjipto Lusida MI, Suryohudoyo P, Adi P, Setiawan PB, Nidom CA, Soemarto R, Katayama Y, Fujii M, Hotta H 2000. Prevalence of GB Virus C/ hepatitis G virus infection among various populations in Surabaya, In- donesia, and identification of novel groups of sequence variants. J Clin Microbiol 38: 662-668.

Hassan H, Bastani B 2000. Hepatitis G virus infection among hemodialysis patients: true infection or innocent bystander. Sem in Dial 13: 108-111.

Katayama K, Kageyama T, Hoshino FB, Fukushi S, Kurihara C, Ishiyama N, Okamura H, Oya A 1998. Full-lengh GBV$\mathrm{C} / \mathrm{HGV}$ genomes from nine Japanese isolates: characterization by comparative analyses. Arch Virol 143: 1063-1075.

Konomi N, Miyoshi C, Zerain CF, Li T, Arakawa Y, Abe K 1999. Epidemiology of hepatitis B, C, E and G virus infection and molecular analysis of hepatitis $\mathrm{G}$ isolates in Bolivia. J Clin Microbiol 37: 3291-3295.

Lampe E, Saback FL, Viazov S, Roggendorf M, Niel C 1998. Age-specific prevalence and genetic diversity of GBV-C/ hepatitis G virus in Brazil. J Med Virol 56: 39-43.

Lampe E, Saback FL, Yoshida CFT, Niel C 1997. Infection with GB virus $\mathrm{C} /$ hepatitis $\mathrm{G}$ virus in Brazilian hemodialysis and hepatitis patients and asymptomatic individuals. J Med Virol 52: 61-67.

Linnen J, Wages J, Zhang-Zeck ZY, Fry KE, Krawczynski KZ, Alter H, Koonin E, Gallagher M, Alter M, Hadziyannis S, Karayiannis P, Fung K, Nakatsuji Y, Shih JWK, Young L, Piatak Jr M, Hoover C, Fernandez J, Chen S, Zou JC, Morris T, Hyams KC, Ismay S, Lifson JD, Hess G, Foung SKH, Thomas H, Bradley D, Margolis H, Kim JP 1996. Molecular cloning and disease association of hepatitis G virus: a transfusion transmissible agent. Science 271: 505508.

Masuko K, Mitsui T, Iwano K, Yamazaki C, Okuda Kenji, Meguro T, Murayama N, Inoue T, Tsuda F, Okamoto H, Miyakawa Y, Mayumi M 1996. Infection with hepatitis GB virus $\mathrm{C}$ in patients on maintenance hemodialysis. $N$ Engl J Med 334: 1485-1490.

Medina M, Ashby M, Schlüter V, Hill M, Leclerq B, Pennell P, Jeffers LJ, Reddy KR, Schiff ER, Hess G, Perez GO 1998. Prevalence of hepatitis $\mathrm{C}$ and $\mathrm{G}$ virus infection in chronic hemodialysis patients. Am J Kid Dis 31: 224-226.

Muerhoff AS, Simons JN, Leary TP, Erker JC, Chalmers ML, Pilot-Matias TJ, Dawson GJ, Desai SM, Mushahawar IK 1996. Sequence heterogeneity within the 5 '-terminal region of the hepatitis GB virus $\mathrm{C}$ genome and evidence for genotypes. J Hepatol 25: 379-384.

Muerhoff AS, Smith DB, Leary TP, Erker JC, Desai SM, Mushahwar IK 1997. Identification of GB virus C variants by phylogenetic analysis of 5'-untranslated and coding region sequences. J Virol 71: 6501-6508.

Muerhoff AS, Tillmann HL, Manns MP, Dawson GJ, Desai SM 2003. GB virus $C$ genotype determination in GB virus C/HIV co-infected individuals. J Med Virol 70:141-149.

Mukaide M, Mizokami M, Orito E, Ohba K, Nakano T, Ueda R, Hikiji K, Iino S, Shapiro S, Lahat N, Park YM, Kim BS, Oyunsuren T, Rezieg M, Al-Ahdal MN, Lau JYN 1997. Three different GB virus C/hepatitis $\mathrm{G}$ virus genotypes. Phylogenetic analysis and a genotyping assay based on restriction fragment length polymorphism. FEBS Lett 407: 51-58.

Naito H, Hayashi S, Abe K 2000. The entire nucleotide sequence of two hepatitis $\mathrm{G}$ virus isolates belonging to a novel genotype: isolation in Myanmar and Vietnam. J Gen Virol 81: 189-194.

Okamoto H, Nakano H, Inoue T, Fukuda M, Kishimoto J, Ilizuda H, Tsuda F, Miyakawa Y, Mishiro M 1997. The entire nucleotide sequence of two GB virus C/hepatitis G virus isolates of distinct genotypes from Japan. J Gen Virol 78: 737-745. 
Oliveira LA, Martins RMB, Carneiro MAS, Teles SA, Silva SA, Cardoso DDP, Lampe E, Yoshida CFT 2002. Prevalence and genotypes of $\mathrm{GB}$ virus $\mathrm{C} /$ hepatitis $\mathrm{G}$ virus among blood donors in Central Brazil. Mem Inst Oswaldo Cruz 97: 953-957.

Quarleri JF, Mathet VL, Feld M, Ferrario D, Della Lata MP, Verdun R, Sánchez DO, Oubinã JR 1999. GB virus C/hepatitis $\mathrm{G}$ virus groups and subgroups: classification by a restriction fragment length polymorphism method based on phylogenetic analysis of the 5' untranslated region. J Clin Microbiol 37: 1340-1347.

Shibuya A, Takeuchi A, Kamata K, Saigenji K, Kobayashi N, Yoshida A 1998. Prevalence of hepatitis G virus RNA and anti-E2 in a Japonese haemodialysis population. Nephrol Dial Transplant 13: 2033-2036.

Simons JN, Leary TP, Dawson GJ, Pilot-Matias TJ, Muerhoff AS, Schlauder GG, Desai SM, Mushahwar IK 1995. Isolation of a novel virus-like sequence associated with human hepatitis. Nature Med 1: 564-569.

Szabo A, Viazov S, Heemann U, Kribben A, Philipp T, Roggendorf M 1997. GBV-C/HGV infection in renal dialysis and transplant patients. Nephrol Dial Transplant 12: 2380-2384.

Tanaka Y, Mizokami M, Orito E, Ohba K, Nakano T, Kato T, Kondo Y, Ding X, Ueda R, Sonoda S, Tajima K, Miura T, Hayami M 1998. GB virus $\mathrm{C} /$ hepatitis $\mathrm{G}$ virus infection among Colombian native Indians. Am J Trop Med Hyg 59: 462-467.

Tillmann HL, Heiken H, Botor-Knapik A, Heringlake S, Ockenga J, Wilber JC, Goergen B, Detmer J, McMorrow M, Stoll
M, Schmidt RE, Manns MP 2001. Infection with GB virus $\mathrm{C}$ and reduced mortality among HIV-infected patients. $N$ Engl J Med 345: 715-724.

Tucker TJ, Smuts HE 2000. GBV-C/HGV genotypes: proposed nomeclature for genotypes 1-5. J Med Virol 62: 82-83.

Tucker TJ, Smuts HE, Eickhaus P, Robson SC, Kirsch RE 1999. Molecular characterization of the 5' non-coding region of South African GBV-C/HGV isolates: major deletion and evidence for a fourth genotype. J Med Virol 59: 52-59.

Tsuda F, Hadiwandowo S, Sawada N, Fukuda M, Tanaka T, Okamoto H, Miyakawa Y, Mayumi M 1996. Infection with GB virus $\mathrm{C}(\mathrm{GBV}-\mathrm{C})$ in patients with chronic liver disease or on maintenance hemodialysis in Indonesia. J Med Virol 49: 248-252.

Watanabe MA, Milanezi CM, Silva WA Jr, de Lucena Angulo I, Santis G, Kashima S, da Costa JA, Neto MM, Covas DT 2003. Molecular investigation of GB virus C RNA in hemodialysis and thalassemics patients from Brazil. Ren Fail 25: 67-75.

Xiang J, Wunschmann S, Dikema DJ, Klinzaman D, Patrick KD, George SL, Stapleton JT 2001. Effect of coinfection with $\mathrm{GB}$ virus $\mathrm{C}$ on survival among patients with HIV infection. N Engl J Med 345: 707-714.

Yeo AET, Matsumoto A, Hisada M, Shih JM, Alter HJ, Goedert JJ 2000. Effect of hepatitis G virus infection on progression of HIV infection in patients with hemophilia. Ann Intern Med 132: 959-963.

Zhu WF, Yin LM, Li P, Huang J, Zhuang H 2003. Pathogenicity of GB virus $\mathrm{C}$ on virus hepatitis and hemodialysis patients. Word J Gastroenterol 9: 1739-1742. 
